\title{
The vigour of timothy (Phleum pratense L.) seeds stored up to 5 years
}

\author{
RYSZARD J. GÓRECKI. DOROTA MIERZEJEWSKA
}

Department of Plant Physiology and Biochemistry, University of Agriculture and Technology, Kortowo 40, 10-957 Olsztyn, Poland

(Received: September 12, 1988. Accepted: December 12, 1988)

\begin{abstract}
The viability and vigour of timothy seeds from the 1982, 1983, 1984, 1985 and 1986 harvests, stored in a store-house under ambient conditions were studied. During five years of storage, seed viability dropped from $90-95 \%$ to below $15 \%$. The greatest fall in viability occurred between the 4 th and 5 th year of storage. Seed viability loss was accompanied by rapid vigour degradation as indicated by soil emergence, seedling growth rate analysis, osmotic stress, ethanol, and accelerated ageing (AA-test) tests. The conductivity test was not useful in timothy vigour examination. The highest correlation coefficients between vigour tests and field emergence were obtained for the seedling growth rate analysis and osmotic stress test.
\end{abstract}

Key words: ageing, seed vigour, timothy, viability

\section{INTRODUCTION}

Seeds harvested at full maturity and stored during shorter (farm and retail storage) or longer (seed reserves, genus banks) periods of time undergo ageing. Three groups of factors determine the rate of seed ageing: 1) genetic seed properties, 2) conditions of seed ripening on maternal plants, 3) storage conditions, mainly seed moisture, air humidity, and temperature (Harring- 
ton 1973, Roberts 1981, Bewley and Black 1982, Roos 1986, Grzesiuk and Kulka 1988).

Although there is a great deal of literature concerning the morphological, structural and biochemical changes associated with seed ageing, the cause of ageing in seeds has remained obscure (Roos 1980, Anderson and Baker 1983, Grzesiuk et al. 1983, Harman and Stasz 1986, Priestely 1986). Reduction of seed vigour and viability are visible symptoms of seed deterioration (Copeland 1976, Górecki 1986). It is important from the practical point of view to know how fast and in what range stored seeds loose their sowing quality. This problem is little explored in grasses. To date, the quality of grass seeds is evaluated mainly by the germination test. Such examination of seed quality, however, is incomplete and inadequate to seedling establishment in field conditions. Thus it seems necessary to introduce a vigour parameter for determination of grass seed quality.

In this work the viability and vigour of naturally aged thimothy seeds were studied using several different methods.

\section{MATERIALS AND METHODS}

Timothy (Phleum pratense L.) cv. Bartovia seeds stored for 1, 2, 3, 4 and 5 years were used in the studies. The seed lots were stored in linen bags in a store-house under ambient conditions until 1987, when all of the experiments were performed.

Laboratory germination. One hundred seeds were placed in a Petri dish on filter paper (Whatman No. 3) moistened with distilled water. After 5 and 10 days of incubation at $20^{\circ} \mathrm{C}$ in darkness, germination rate and germination capacity were recorded, respectively.

DETERMINATION OF SEED VIGOUR

Seedling growth rate. Fifty seeds were put between moistened rolled filter paper at $20^{\circ} \mathrm{C}$. After 5 and 10 days of germination, the lengths of the radicle and coleoptile and the fresh mass of the seedlings were determined.

Conductivity of seed leachates. One gram of seeds was rinsed with deionised water, next soaked in $100 \mathrm{~cm}^{3}$ deionised water at $20^{\circ} \mathrm{C}$ for 24 hours. The electrical conductivity of the leachates was measured using a conductivity bridge. 
Ethanol stress test. Seed samples were treated with $5 \%, 10 \%, 15 \%$ and $20 \%$ (v/v) aequous ethanol at $20^{\circ} \mathrm{C}$ for 2, 4, 6 and 24 hours and later tested for germination as above.

Osmotic stress test. One hundred seeds of each sample were germinated in the presence of $4 \mathrm{~cm}^{3} 15 \%(-0.318 \mathrm{MPa}), 16 \%(-0.336 \mathrm{MPa}), 17 \%(-0.395$ $\mathrm{MPa})$, or $18 \%(-0.436 \mathrm{MPa})$ polyethylene glycol (PEG) 6000 (Fluka AG) water solutions, at $20^{\circ} \mathrm{C}$. After 5 days of germination, counts of viable seeds were made.

Accelerated ageing test (AA-test). Seed samples (about $20 \mathrm{~g}$ ) were placed in a brass wire basket $(9 \mathrm{~cm})$. supported on three $5 \mathrm{~cm}$ long legs. The basket was placed in a plastic box containing a $2 \mathrm{~cm}$ layer of water, providing $100 \%$ relative air humidity. The box was covered and kept at $40^{\circ} \mathrm{C}$. After 2 days of ageing the viability of the seeds was determined and compared to that of unaged seeds (control).

Field and greenhouse emergence. Seed samples $(100$ seeds $\times 8)$ were sown on May 4 (greenhouse) and on May 25 (field) by hand. $5 \mathrm{~mm}$ deep in rows $1 \mathrm{~m}$ long in a medium brief soil. The emerged seedlings were counted after 21 days from the first observed emergence.

All germination and vigour tests were performed at least four times in two replications and the results were subjected to the statistical analysis (standard deviations and correlation coefficients were calculated).

\section{RESULTS AND DISCUSSION}

GERMINATION AND SOIL EMERGENCE

The germination capacity of timothy seeds determined shortly after harvest was $90-95 \%$. During seed storage under ambient conditions in a store-house, gradual degradation of their viability was noted (Fig. 1). After 5 years of storage the germination rate was about $5 \%$ but germination capacity decreased to below $20 \%$. The highest degradation of viability occurred between the 4th and 5th year of storage. A similar rate of viability loss was observed in ageing cocksfoot seeds (Gó recki et al. in press). The seed viability determined in the laboratory was distinctly higher than field seedling emergences, and was similar to greenhouse emergences (Fig. 2). In case of one and two-year-old seeds, field emergences were lower by ca. $30-35 \%$ in comparison with germination capacity. Generally, as ageing progressed the seed ability to emerge in soil was reduced, reaching a level of $8 \%$ in 5 year-old seeds. 


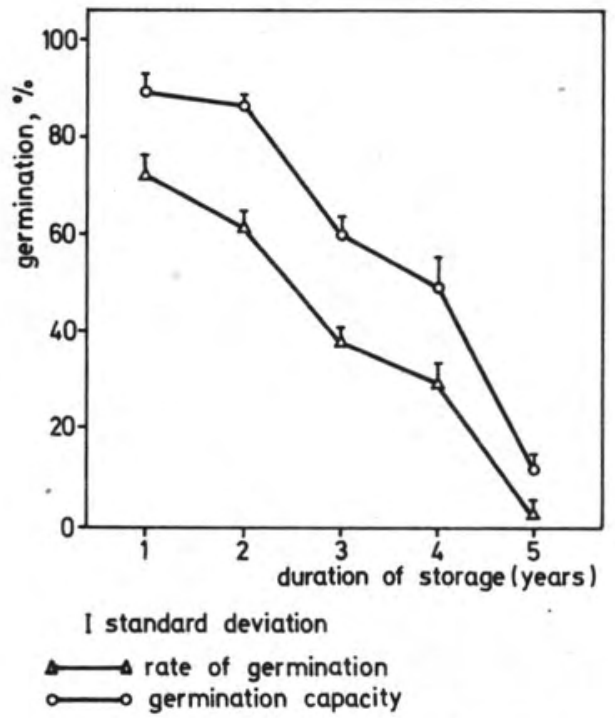

Fig. 1. Germination of timothy seeds from different harvest years

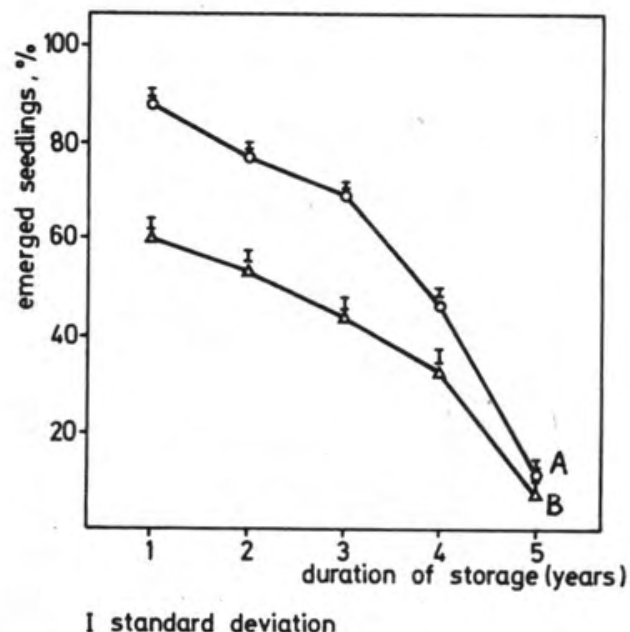

Fig. 2. Greenhouse (A) and field emergence (B) of timothy seeds from different harvest years,

The inconsistency between laboratory germination and sowing quality of grasses has been known in seed science and seed production for a long time (Hebblethwaite 1980). A better indicator of seed quality seems to be vigour, if determined by suitably adjusted methods (Grzesiuk and Górecki 1981). 
The loss of vigour related to the duration of storage was observed when the growth rate of seedlings raised from timothy seeds was measured (Table 1). Measurements of coleoptile and radicle lengths were a more sensitive vigour indicator than the fresh mass of seedling. The comparison of data from Table 1 with correlation coefficients (Table 4) shows that the analyses of seedling growth rate of timothy seeds should be carried out after 5 days of germination.

Table 1

The growth rates of timothy seedlings from seeds of different ages

\begin{tabular}{|c|c|c|c|c|c|c|}
\hline \multirow{2}{*}{$\begin{array}{c}\text { Duration of } \\
\text { storage } \\
\text { (years) }\end{array}$} & \multicolumn{2}{|c|}{$\begin{array}{c}\text { Mean coleoptile length, } \\
\mathrm{mm}\end{array}$} & \multicolumn{2}{c|}{$\begin{array}{c}\text { Mean radicle length, } \\
\mathrm{mm}\end{array}$} & \multicolumn{2}{c|}{$\begin{array}{c}\text { Whole seedling fresh weight, } \\
\mathrm{mg}\end{array}$} \\
\cline { 2 - 7 } & $\begin{array}{c}\text { after } 5 \\
\text { days }\end{array}$ & $\begin{array}{c}\text { after } 10 \\
\text { days }\end{array}$ & $\begin{array}{c}\text { after } 5 \\
\text { days }\end{array}$ & $\begin{array}{c}\text { after } 10 \\
\text { days }\end{array}$ & $\begin{array}{c}\text { after } 5 \\
\text { days }\end{array}$ & $\begin{array}{c}\text { after 10 } \\
\text { days }\end{array}$ \\
\hline 1 & $10.2 \pm 0.9$ & $30.3 \pm 1.8$ & $17.7 \pm 1.4$ & $26.6 \pm 1.7$ & $1.3 \pm 0.1$ & $1.7 \pm 0.1$ \\
2 & $9.8 \pm 0.6$ & $22.2 \pm 2.8$ & $17.9 \pm 1.0$ & $20.7 \pm 2.3$ & $1.3 \pm 0.1$ & $1.9 \pm 0.2$ \\
3 & $4.8 \pm 1.1$ & $27.7 \pm 1.5$ & $8.7 \pm 1.8$ & $25.8 \pm 1.1$ & $1.2 \pm 0.3$ & $1.9 \pm 0.0$ \\
4 & $3.3 \pm 0.3$ & $16.6 \pm 1.0$ & $6.6 \pm 0.7$ & $16.0 \pm 0.8$ & $1.0 \pm 0.1$ & $1.8 \pm 0.1$ \\
5 & $0.3 \pm 0.1$ & $3.4 \pm 0.7$ & $0.6 \pm 0.1$ & $3.7 \pm 1.0$ & $0.9 \pm 0.2$ & $1.5 \pm 0.3$ \\
\hline
\end{tabular}

\pm - Standard deviation.

Marshall and Naylor (1985) observed a positive correlation between field emergence and the controlled deterioration test. In our studies the AA-test was used at $40^{\circ} \mathrm{C}$ and $100 \%$ relative air humidity. Regardless of age, two-day seed storage caused a rapid degradation of germinability (Table 2). It is important to note that the younger seeds (from 1985 and 1986) showed a smaller degradation of germination than the older ones. This would then

Table 2

Percentage laboratory germination after accelerated ageing (at 100\% R.H. and $40^{\circ} \mathrm{C}$ ) of timothy seeds from different harvest years

\begin{tabular}{|c|c|c|}
\hline Duration of storage, years & Germination rate & Germination capacity \\
\hline 1 & $67.5 \pm 5.6$ & $88.5 \pm 2.2$ \\
2 & $58.5 \pm 2.8$ & $86.5 \pm 2.1$ \\
3 & $10.0 \pm 2.0$ & $35.0 \pm 1.9$ \\
4 & $7.0 \pm 2.9$ & $17.5 \pm 4.5$ \\
5 & 0 & $1.0 \pm 1.0$ \\
\hline
\end{tabular}


indicate an increased seed vigour level of one and two-year old seeds. This is confirmed by results of the field and greenhouse emergence analysis (Fig. 2).

The speed of seed deterioration under alcohol stress could be a vigour measure (Musgrave et al. 1980). Timothy seed germination depended on the ethanol concentration, stress duration and seed age. Treating seeds with $5 \%$ and $10 \%$ ethanol solutions resulted in rather small changes in the germination rate (Fig. 3). Evident viability degradation was seen in $15 \%$ and $20 \%$ ethanol solutions. Five-year old seeds exihibited more rapid reaction to stress than seeds from the last years harvest. A similar response to ethanol stress was found out in cocksfoot seeds (Górecki et al. in press). Table 4 shows, however, that the ethanol stress test results correlated rather poorly with field emergences. In contrast, to our findings, Mugnisja h and Naka mu ra (1986) showed the usefulness of the ethanol test for soybean seed vigour evaluation.
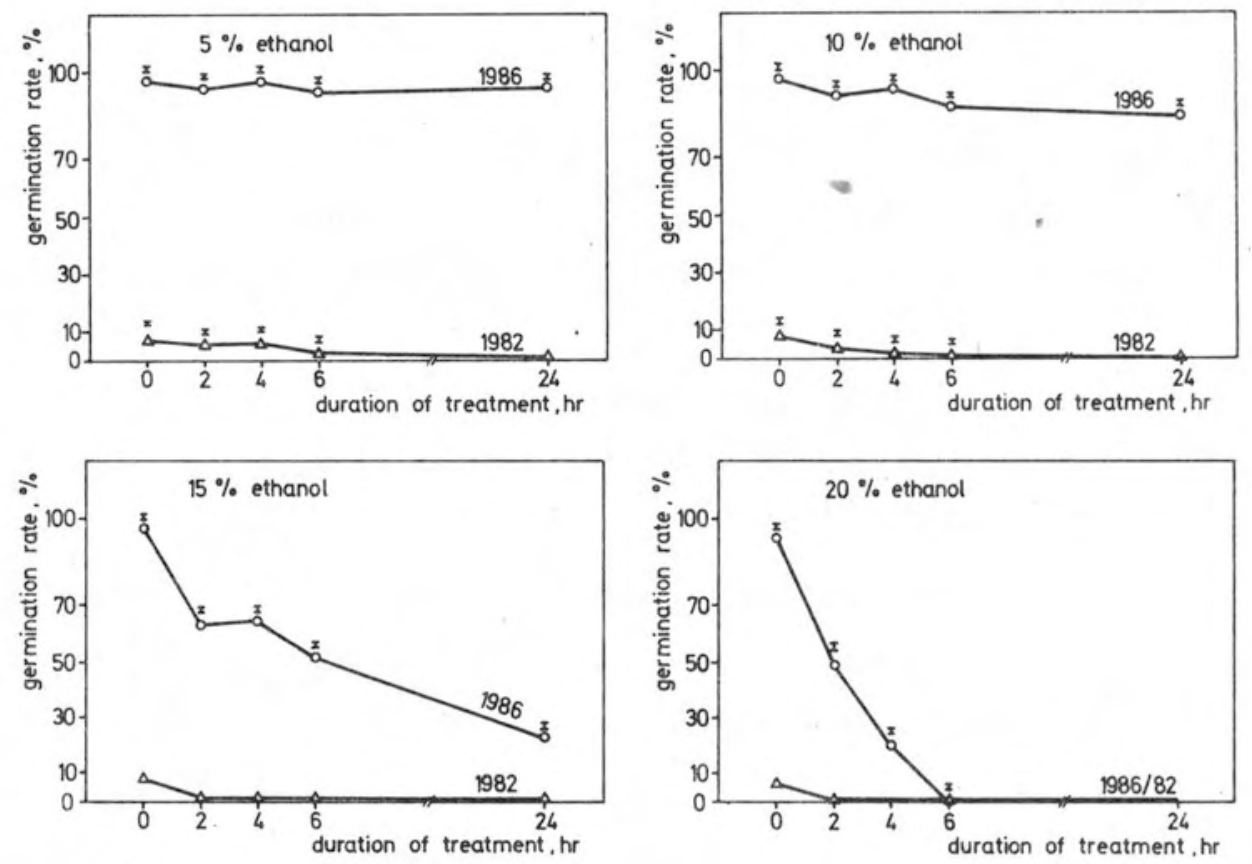

I standard deviation

Fig. 3. Germination rate of timothy seeds from the 1986 and 1982 harvests, treated with different concentrations of ethanol solutions for 2, 4, 6 and 24 hours

Shallow sowing of grass seeds often subjects them to drought. The ability of seeds to produce seedlings in water deficiency can be regarded as one of the indicators of their quality (Anonymous 1983). Earlier experiments (Górecki et al. in press) indicated that moderate osmotic stress (up to $-0.16 \mathrm{MPa}$ ) did not influence cocksfoot seed germination. Only the decrease of osmotic 
potential to below $-0.30 \mathrm{MPa}$ (above $15 \%$ PEG) limited seed germination significantly. Therefore, $15 \%, 16 \%, 17 \%$, and $18 \%$ solutions with osmotic potentials from $-0.43 \mathrm{MPa}$ to $-0.318 \mathrm{MPa}$ were used in this investigation (Table 3). PEG at concentration $15 \%$ decreased the germination rate sig-

Table 3

The germination rate of timothy seeds under osmotic stress

\begin{tabular}{|c|c|c|c|c|c|}
\hline \multirow{2}{*}{$\begin{array}{c}\text { Duration } \\
\text { of storage, } \\
\text { years }\end{array}$} & $\mathrm{H}_{2} \mathrm{O}$ & $\begin{array}{c}\text { Osmotic potential (MPa) } \\
(15 \%)^{*} \\
-0.318\end{array}$ & $\begin{array}{c}(16 \%)^{*} \\
-0.356\end{array}$ & $\begin{array}{c}(17 \%)^{*} \\
-0.395\end{array}$ & $\begin{array}{c}(18 \%)^{*} \\
-0.436\end{array}$ \\
\cline { 2 - 6 } & $92.5 \pm 1.2$ & $82.8 \pm 6.8$ & $64.3 \pm 5.5$ & $45.3 \pm 5.0$ & $15.3 \pm 3.8$ \\
\hline 1 & $93.5 \pm 1.5$ & $58.5 \pm 4.4$ & $50.8 \pm 3.9$ & $34.0 \pm 3.1$ & $12.8 \pm 1.9$ \\
\hline 3 & $70.5 \pm 2.4$ & $24.0 \pm 3.2$ & $21.0 \pm 2.1$ & $13.0 \pm 2.4$ & $5.3 \pm 1.1$ \\
\hline 4 & $37.8 \pm 2.2$ & $23.8 \pm 3.1$ & $8.3 \pm 2.0$ & $6.3 \pm 2.0$ & $1.3 \pm 0.7$ \\
\hline 5 & $6.3 \pm 1.8$ & $1.5 \pm 0.5$ & $0.3 \pm 0.3$ & $0.8 \pm 0.5$ & 0 \\
\hline
\end{tabular}

- Perecent concentration of PEG solution. \pm - Standard deviation.

nificantly, but not as much as other solutions. Similarly as in the case of ethanol stress, older seeds responded more strongly than one and two-year old ones. Considering the practical use of osmotic stress it seems evident that the germination rate in $15 \%$ and $16 \%$ PEG is the best indicator of timothy seeds vigour. It correlated well with field emergence (correlation coefficients $0.82-0.74$, Table 4).

The conductivity test did not support the regularities found earlier by other tests, concerning vigour degradation of ageing timothy (Fig. 4). The conductivity of seed leachates differed significantly among the analysed seed lots, but was smaller in older seed lots (harvested in 1982 and 1983) than in younger ones (harvested in 1985 and 1986). This finding suggests that cell membrane degradation during seed ageing is rather improbable. However, such a statement is inconsistent with very common literature data showing that during ageing seed membrane perturbation occurs, as detected by a high increase of electrolytes leakage from seed tissues (Bewley and Black 1982, Harman and Stasz 1986, Powell 1986). 
Table 4

Correlations of field emergence with viability and vigour indicators of timothy seeds

\begin{tabular}{|c|c|c|}
\hline Indicator & \multicolumn{2}{|c|}{ Correlation coefficient } \\
\hline Germination capacity & \multicolumn{2}{|c|}{$0.85^{* *}$} \\
\hline Rate of germination & \multicolumn{2}{|c|}{$0.61^{* *}$} \\
\hline Greenhouse emergence & \multicolumn{2}{|c|}{$0.94 * *$} \\
\hline $\begin{array}{c}\text { Seedling growth rate after } 5 \\
\text { and } 10 \text { days }\end{array}$ & 5 days & . 10 days \\
\hline $\begin{array}{l}\text { Coleoptile length } \\
\text { Radicle length } \\
\text { Seedling fresh weight }\end{array}$ & $\begin{array}{l}0.71 \\
0.77^{* *} \\
0.71\end{array}$ & $\begin{array}{l}0.55^{* *} \\
0.30 \\
0.32^{*}\end{array}$ \\
\hline $\begin{array}{c}\text { Osmotic stress } \\
15 \% \\
\begin{array}{ll}16 \% & \text { PEG } \\
17 \% & \text { PEG } \\
18 \% & \text { PEG }\end{array}\end{array}$ & & \\
\hline $\begin{array}{l}\text { Ethanol stress, } 10 \% \\
2 \mathrm{hr} \\
4 \mathrm{hr} \\
6 \mathrm{hr} \\
24 \mathrm{hr}\end{array}$ & $\begin{array}{c}1986 \\
0.18 \\
0.14 \\
0.02 \\
-0.76^{*}\end{array}$ & $\begin{array}{c}1982 \\
0.72^{*} \\
0.1 \\
-0.83^{*} \\
0.43\end{array}$ \\
\hline $\begin{array}{l}\text { Ethanol stress, } 20 \% \\
2 \mathrm{hr} \\
4 \mathrm{hr} \\
6 \mathrm{hr} \\
24 \mathrm{hr}\end{array}$ & $\begin{array}{c}1986 \\
-0.46 \\
-0.59 \\
-0.57 \\
0.0\end{array}$ & $\begin{array}{c}1982 \\
-0.8^{*} \\
0.0 \\
0.0 \\
0.0\end{array}$ \\
\hline \multirow{2}{*}{ AA-test } & 5 days & 10 days \\
\hline & $0.58^{* *}$ & $0.41^{*}$ \\
\hline
\end{tabular}

* Significance at $P=0.05, *$ Significance at $P=0.01$.

Figure 4 shows that applying the conductivity test for vigour determination of timothy seeds is useless. Similar conclusions were drawn by $\mathrm{Ching}$ and Schoolcraft (1963), Marshall and Naylor (1985), and Górecki et al. (in press) while examining seed vigour of Italian ryegrass and cockśfoot. In contrast to the above facts the conductivity test is a good indicator for large-seeded legume seeds (Górecki 1986, Powell 1986), cereal grains 


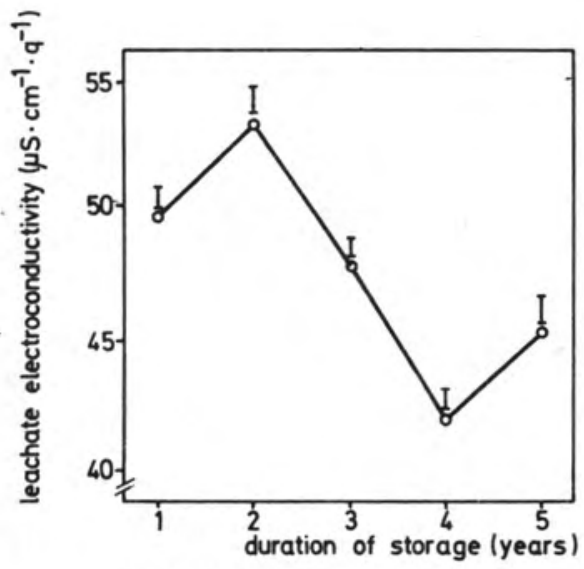

I standard deviation

Fig. 4. Conductivity of timothy seed leachates

(Grzesiuk and Tłuczkiewicz 1982), and small-seeded legume seeds (Grzesiuk and Górecki 1988).

Storage of timothy seeds in ambient conditions leads to quick degradation of their viability and vigour. The vigour decrease was detected by the following tests: seedling growth rate, osmotic stress test, ethanol stress, and AA-test. The conductivity test was not an appropriate technique for timothy seed vigour examination. However, none of vigour test correlated better with field emergence than germination. Thus further studies are necessary to develop techniques of grass seed vigour evaluation. Because resistance of seeds to stress factors may be an indication of seed vigour potential, it seems that improvement of stress methods gives a chance of finding a good vigour test.

\section{REFERENCES}

Anderson J. D., Backer J. E., 1983. Deterioration of seeds during aging. Phytopatology 73: 321-325.

Anonymous, 1983. Seed vigour testing handbook. AOSA.

Bewley J. D., Black M., 1982. Physiology and biochemistry of seeds. II. Viability, dormancy and environmental control. Springer-Verlag, Berlin-Heidelberg-New York.

Ching T. M., Schoolcraft I., 1963. Physiological and chemical differences in aged seed. Crop Sci. 8: 407-409.

Copeland L. O., 1976. Principles of seed science and technology. Burges Publishing Company, Minneapolis.

Górecki R. J., 1986. Studies on vigour of legume seeds. (in Polish) Acta Acad. Agricult. Techn. Olst. 42, Supplementum A, :1-60. 
Górecki R. J., Mierzejewska D., Kaszuba J., Grzesiuk S., Rejowski A., in press. Vigour evaluation of cocksfoot (Dactylis glomerata L.) seeds of different age. Acta Agrobot.

Grzesiuk S., Górecki R. J., 1981. Vigour of seeds as a new criterion of seed quality and methods of its determination. (in Polish) Post. Nauk Roln. 6: 33-56.

Grzesiuk S., Górecki R. J., 1988. Methods of vigour examination of clover and alfalfa seeds (in Russian). Martin-Luther-Universität, Halle-Wittenberg. B. 1.

Grzesiuk S., Kulka K., 1988. Biology of cereal grains. (in Polish) PWN, Warszawa.

Grzesiuk S., Tłuczkiewicz J., 1982. Viability and vigour of ageing winter wheat grains. Acta Soc. Bot. Pol. 51:251-262.

Grzesiuk S., Tłuczkiewicz J., Górecki R. J., 1983. Adenylate energy charge in ageing winter wheat grains. Acta Physiol. Plant 5: 61-69.

Harman G. E., Stasz T. E., 1986. Influence of seed quality on soil microbes and seed rots. CSSA, Spec. Pub. no 12: 11-37.

Harrington J. F., 1973. Biochemical basis of seed longevity. Seed Sci. Technol. 1: 453-461. Hebblethwaite P. D., 1980. Seed production. Butterworths, London-Boston.

Marshall A. H., Naylor R. E., 1985. Seed vigour and field establishment in Italian ryegrass (Lolium multiflorum Lam.) Seed Sci. Technol. 13: 781-794.

Mugnisjah E. Q., Nakamura S., 1986. Methanol and ethanol stress for seed vigour evaluation in soybean. Seed Sci. Technol. 14: 95-103.

Musgrave M. E., Priestley D. A., Leopold C. A., 1980. Methanol stress as a test of seed vigour. Crop Sci. 20: 626-630.

Powell A. A., 1986. Cell membranes and seed leachate conductivity in relation to the quality of seed for sowing. J. Seed Technol. 10: 81-100.

Priestley D. A., 1986. Seed aging. Implications of seed storage and persistance in the soil. Cornell University Press, Ithaca.

Roberts E. H., 1981. Physiology of ageing and its application to drying and storage. Seed Sci. Technol. 9: 359-372.

Ross E. E., 1980. Physiological, biochemical, and genetic changes in seed quality during storage. HortScience 15: 19-26.

Ross E. E., 1986. Precepts of successfull seed storage. Physiology of seed deterioration, CSSA Spec. Pub. no. 11: 1-25.

Wigor nasion tymotki ląkowej (Phleum pratense L.) z różnych lat zbioru

\section{Streszczenie}

Badano jywotność i wigor nasion tymotki łąkowej zbieranych w latach: 1982, 1983, 1984. 1985 oraz 1986 i przechowywanych w magazynie o nie kontrolowanej temperaturze i wilgotności względnej powietrza. Po 5 latach przechowywania żywotność nasion obniżyła się z 90-95\% do poniżej $15 \%$. Największy spadek zdolności kiełkowania nasion nastąpił między 4 a 5 rokiem przechowywania. Utracie żywotności nasion towarzyszyła szybka degeneracja ich wigoru stwierdzona na podstawie wschodów polowych, analizy szybkości wzrostu siewek, testu stresu osmotycznego i etanolowego oraz AA-testu. Metoda konduktometryczna okazała się nieprzydatna do badań wigoru starzejących się nasion tymotki łąkowej. Najwyższe współczynniki korelacj̉i między wschodami polowymi a stosowanymi testami wigorowymi uzyskano dla analizy szybkości wzrostu siewek i testu stresu osmotycznego przy użyciu 15 i $16 \%$ PEG 6000. 